\title{
Estimate Roughness Coefficient and Water Lost During the Flow in the Watercourse Situated in the Pusa Farm
}

\author{
Pappu Kumar Paswan ${ }^{1 *}$, Krishan Murari Sharma ${ }^{2}$ and Sudarshan Prasad ${ }^{3}$ \\ ${ }^{1}$ Krishi Vigyan Kendra, Purnea, (BAU, Sabour, Bhagalpur), India \\ ${ }^{2}$ College of Agricultural Engineering, (Dr. RPCAU PUSA, Samastipur) Bihar, India \\ ${ }^{3}$ Department of Irrigation and Drainage Engineering, College of Agricultural Engineering, \\ (Dr. RPCAU PUSA, Samastipur) Bihar, India \\ *Corresponding author
}

\section{A B S T R A C T}

\begin{tabular}{|l|}
\hline Ke y w o r d s \\
Manning's \\
roughness \\
coefficient, Water \\
losses, weir and \\
Parshall flume
\end{tabular}

The field experiments were conducted to compute the Manning's roughness coefficient initiated during the flow in lined and unlined watercourses located at the Chhounia field near the field of AICRP on IWM and the Brick field beside the KV, Dr. RPCAU, Pusa (Bihar). The average bed slope of the lined watercourse was found to be $1.5 \%$ whereas that of unlined watercourse was observed to be $0.2 \%$. The discharge i.e. rate of water flow was determined in both the lined and unlined watercourses with the help of the weir and the Parshall flume, respectively. The water flow rate in lined watercourse was observed to be $0.0058 \mathrm{~m}^{3} / \mathrm{sec}(5.8 \mathrm{lps})$ while that at upstream and downstream ends of the unlined watercourse were found to be $0.0068 \mathrm{~m}^{3} / \mathrm{sec}(6.8 \mathrm{lps})$ and $0.0062 \mathrm{~m}^{3} / \mathrm{sec}(6.2 \mathrm{lps})$, respectively. The higher depth of flow of $0.162 \mathrm{~m}$ in unlined watercourse than that in lined watercourse $(0.047 \mathrm{~m})$ was observed. The lower cross-sectional area of flow $\left(0.0225 \mathrm{~m}^{2}\right)$ in lined watercourse was observed in comparison of that in unlined watercourse $(0.107$ $\left.\mathrm{m}^{2}\right)$. The velocity of flow were higher in lined water course $(0.269 \mathrm{~m} / \mathrm{s})$ than that in unlined watercourse $(0.069 \mathrm{~m} / \mathrm{s})$. The amount of water lost during the 12 hour operation of unlined watercourse was estimated as 782 litres $/ \mathrm{day} / \mathrm{m}^{2}$.The average conveyance loss of water flow rate per unit wetted area of unlined watercourse was revealed as $0.01811 \mathrm{ps} / \mathrm{m}^{2}$.

\section{Introduction}

In India about $76 \%$ of its population is mainly dependent on agriculture and its allied activities. As far as agriculture is concerned water is one of the most important inputs, adequate and timely supply of which is necessary throughout the crop growing period. Water requirement of the crop vary substantially during the growing period mainly due to variation in crop canopy and climate conditions. The knowledge of crop water requirement is an important practical consideration to improve water use efficiency in irrigated agriculture. Water use for irrigation for instance, accounts for about 70- 
$80 \%$ of the total freshwater available worldwide and irrigation has been ranked as one of the activities that utilize huge amounts of fresh water in many countries. That in the near future, less water will be available for agricultural production due to competition with other sectors.

The irrigation water is supplied to the agricultural fields either through pipe networking in case of pressurized system of irrigation or through open channel in case of surface irrigation system. In order to provide adequate amount of water to meet out the demand of water requirement of all crops, adequate design of an open channel is required.

At the same time, food production will have to be increased to feed the growing world population estimated at 81 million persons per year (UN, 2013) or about 9 billion people by 2050. Among various canal hydraulic parameters, the channel roughness plays very important role in the study of open channel flow. Channel roughness is a highly variable parameter which depends upon number of factors like surface roughness, vegetation cover, channel irregularities and channel alignment (Datta et al., 1997). The channel roughness is not a constant parameter and it varies along the selected canal reach depending upon variation in channel characteristic along the flow.

Several researchers including have calibrated channel roughness for different channels for the development of hydraulic mode lestimating single channel roughness value for open channel flow using optimization method, taking the boundary condition as constraints (Parhi et al., 2012). Estimation of channel roughness coefficients will enable accurate and reliable decision making support to design the open channel and manage the irrigation water for sustainable crop product.
An open channel is a conduit in which water flows under atmospheric pressure. Open channel flow describes the flow of water with air above the flow forming free surface at top. As water flow in open channel, it is influenced only by friction with the bed and the sides of the channel. With the flow of water in the channel in this case, water flows with a uniform depth (normal depth) at which the weight component in the direction of the flow balances with the friction force induced by the flow resistance with the bed and sides (Chow, 1559).

Many equations were developed to relate the bed roughness with the flow parameters in open channels. Among these, the most widely used equation is the Manning equation which correlates the flow velocity and the cross sectional parameters with the Manning's coefficient (n) which is a function in the roughness of bed material. The hydraulic characteristics of open channel that influence the roughness coefficient ' $n$ ' in Manning's equation are surface roughness, type of vegetation in bed and sides of the channel, channel size, shape and its irregularity. It should be noted that these factors are to a certain extent interdependent (Mitraet et al., 2016).

Furthermore, due to these parameters, the roughness of the channel is not equally distributed over the channel. So, using literature data does not always lead to satisfactory results, due to the different situation in the field. Therefore, measurements are necessary to determine the variation of the Manning's coefficient. Moreover, when water flows in an open channel, total energy is lost due to the friction between the flow and the surface roughness on the bed and side of the channel. Sometimes, the loss in energy is recorded due to the turbulence developed during the flow. (Khatua et al., 2012) 


\section{Materials and Methods}

This chapter deals with the materials used during the experiment to measure the hydraulic parameters such as the rate of flow, bed slope of watercourses, cross-sectional area of flow and wetted perimeter of flow in watercourses and the methodology used to compute the Manning's roughness coefficient caused during the flow in the watercourses. The determination of conveyance loss i.e. the amount of water lost during the flow and conveyance efficiency of unlined watercourses has also been attempted.

\section{Experimental site}

The experiments were conducted in a lined and unlined watercourses located at Chhounia field near the experimental plot of AICRP on Irrigation Water Management (Fig. 1) and Brick field beside the Kendriya Vidyalya Pusa (Fig. 2), respectively. Pusa is situated on the bank of the river Budhi Gandak in the Samastipur district of North Bihar. It has latitude of $25^{\circ} 29^{\prime}$ North, a longitude of $83^{\circ}$ $48^{\prime}$ East and at an altitude of 52.92 meter above mean sea level. Pusa is endowed with fair climate having average annual rainfall of $1200 \mathrm{~mm}$.

\section{Equipments}

The under mentioned instruments were used during the conduct of the present experiment in order to determine Manning's roughness coefficient, the rate of water lost during the flow and the conveyance efficiency of the watercourses.

\section{Rectangular weir}

A rectangular weir is a device which was used to measure the flow in lined water course. It is a notch of rectangular shape through which irrigation water is allowed to flow. The head over the rectangular weir was measured with the help of scale and with the water flow rate through the open channel was determined.

\section{Parshall flume}

The Parshall flume, a self-cleaning device used for direct measurement of rate of flowing water in a watercourse, was used to determine the discharge of water in the unlined watercourse. The flume of width size of $7.5 \mathrm{~cm}$ was installed in the unlined watercourse under partially submerged condition. It has three parts, a converging section at its upstream end, a throat in its middle section and a diverging section at its downstream end.

\section{Dumpy level}

The dumpy level a telescopic device was used during the experiment to determine the slope of channel bed for both the lined and unlined water courses as well. The level was set up at position just beside the channels section and levelled. Thus, the reduced level at the upstream and downstream of the channel section selected at a distance of $16 \mathrm{~m}$ apart and located at the Chhounia field was determined. The difference in elevations, thus determined gave the vertical drop at the downstream end of the channel. However, in case of the watercourses located beside the $\mathrm{KV}$, the reduced level at the interval of $5 \mathrm{~m}$ between the upstream and the downstream of the channel section selected at a distance of $30 \mathrm{~m}$ apart was determined. During the determination of elevations, the bench mark (BM) of $100 \mathrm{~m}$ at the upstream end of both the watercourses was arbitrarily assumed.

\section{Levelling staff}

Sop- with telescopic staff, a graduated wooden rod of $4 \mathrm{~m}$ in length and arranged in three length placed one into the other, was 
used for measuring the vertical distance between the ends of the channel section and the line of collimation. The staff was held at both the ends in a vertical position and the readings were recorded.

\section{Discharge measurement in watercourse}

The depth of flow, wetted perimeter and cross-sectional area of both the watercourses were measured with tap. The bed slope of selected sections of both lined and unlined watercourses was determined with the help of dumpy level and the level staff. The discharge flowing through the lined and unlined watercourses were measured using the weir and the Parshall flume, respectively.

After determining the velocity of flow of water in the watercourses, the Manning's roughness coefficient was determined. It has also been attempted to estimate the rate of water lost between the selected sections of the unlined watercourse and the conveyance efficiency as well.

\section{Computation of discharge using rectangular weir}

The discharge through rectangular weir for both end-contracted and installed in lined watercourse was computed by the Francis's formula as mentioned below:

$Q=0.0148(L-0.2 H) H^{3 / 2}$

Where,

$\mathrm{Q}=$ discharge in watercourse, litres/second

$\mathrm{L}=\quad$ length of weir crest, $\mathrm{cm}$

$\mathrm{H}=$ head over the weir, $\mathrm{cm}$

Determination of discharge using parshall flume

The Parshall flume that is simple in construction and common in use to measure the small discharge of flow in watercourse was used to the measure the rate of flow in unlined watercourse under partial submergence condition. The heads at the upstream $\left(h_{a}\right)$ and downstream $\left(h_{b}\right)$ of the flume was measured and the degree of submergence was determined.

Percentage of submergence $=\frac{h_{b}}{h_{a}} \times 100$

Robinson (1957) calibrated chart between percentage of submergence and upstream head for determination of discharge through the Parshall flume installed under submerged condition, was used to determine the discharge in unlined water course under study.

\section{Determination of bed slope of watercourse}

The bed slope of lined and unlined watercourses under study was estimated using following equation:

$$
\mathrm{S}=\frac{\mathrm{h}}{\mathrm{L}}
$$

Where,

$\mathrm{h}=$ vertical drop between the elevations measured at the sections of the watercourses.

$\mathrm{L}=$ length of section of the watercourse.

\section{Determination of cross-sectional area of unlined watercourse}

The cross-section area of the unlined watercourse was determined with the help of under mentioned formula.

$$
\mathrm{A}={ }^{\frac{2}{3}} \mathrm{t} \times \mathrm{d}
$$

Where,

$\mathrm{t}=$ top width of the watercourse, m. 
$\mathrm{d}=$ depth of flow in the watercourse, $\mathrm{m}$.

Computation of manning's roughness coefficient

The roughness coefficient (n) for the flow in both the lined and unlined watercourses was determined with the help of Manning's formula as mentioned bellow:

$\mathrm{n}=\frac{R^{2 / 8} s^{1 / 2}}{V}$

Where,

$\mathrm{R}=$ hydraulic radius of the watercourse, $\mathrm{m}$.

$\mathrm{S}=$ hydraulic slope of the watercourse in decimal.

$\mathrm{V}=$ mean velocity of flow in the watercourse, $\mathrm{m} / \mathrm{s}$.

Estimation of conveyance loss in unlined watercourse

The water lost during the flow in unlined watercourse under study was attempted to determine. The loss of water during flow was determined in terms of seepage rate per unit length of the watercourse, percentage of water loss and in terms of seepage rate per unit wetted area by using the formula as mentioned below.

\section{Computation of conveyance loss per unit length of watercourse}

$Q_{L}=\frac{Q_{1}-Q_{2}}{L}$

Where,

$\mathrm{Q}_{\mathrm{L}}=$ conveyance lossper unit length (lps/m)

$\mathrm{Q}_{1}=$ initial rate of the channel section, lps
$\mathrm{sQ}_{2}=$ outflow rate of water from the channel section, lps

Estimation of percentage water loss

$Q_{L P}=\frac{Q_{1}-Q_{2}}{Q_{1}} \times 100$

Estimation of rate of water loss per unit wetted area

$Q_{l A W}=\frac{Q_{1}-Q_{2}}{A_{W}}$

Computation of conveyance efficiency of watercourse

$\eta_{C}=100-Q_{L P}$

Where,

$\mathrm{Q}_{\mathrm{LP}}=$ percentage rate of water lost through the channel.

$\mathrm{Q}_{\mathrm{LAW}}=$ rate of water lost per unit wetted area of channel, $1 \mathrm{ps} / \mathrm{m}^{2}$

$\mathrm{A}_{\mathrm{W}}=$ wetted area of the unlined watercourse, $\mathrm{m}^{2}$

$\eta_{C}=$ conveyance efficiency of unlined watercourse, $\%$.

\section{Results and Discussion}

The present study was taken up to compute the Manning's roughness coefficient initiated during the flow in lined and unlined watercourses located at the Chhounia field and the Brick field beside the Kendriya Vidyalaya (KV), under Dr. RPCAU, Pusa (Bihar).

The conveyance loss i.e. the rate of water lost during the flow in unlined watercourses in terms of per unit length and per unit wetted area of the flow and its conveyance efficiency were also attempted to determine. The percentage loss of rate of flow water in the unlined watercourse was also determined. 


\section{Determination of bed slope of watercourses}

The slope of both the water courses was determined using the dumpy level and the level staff. A $16 \mathrm{~m}$ straight section of lined watercourse located at Chhounia field was selected and the reduced levels at upstream end, middle section and downstream end were determined. Thus, calculated values of reduced levels were presented in Table 1. It can be clearly seen from the Table 1 that the same value of bed slope $(1.5 \%)$ of the lined watercourse in all observations were observed.

On the other hand, a $30 \mathrm{~m}$ almost straight unlined watercourse located at Brick field beside Kendriya Vidyalaya was selected and the selected section of the unlined watercourse was divided into six test sections each of $5 \mathrm{~m}$ in length. The reduced level at the end of every test sections were computed and presented in Table 2. Table 2 shows the estimated bed slope of the test sections. It can be inferred from the above discussions that the average bed slope of the lined watercourse was found to be $1.5 \%$ whereas the weighted average of bed slope of unlined watercourse was observed to be $0.2 \%$.

\section{Measurement of water flow rate in watercourses}

The discharge i.e. rate of water flow was determined in both the lined and unlined watercourses with the help of the weir and the Parshall flume, respectively. The weir was installed in the lined watercourse both ends supported by earthen loose soil and water was allowed to flow through the weir. After sometime of installation when the flow gets stabilised, the length of the weir crest and the head of flow were measured and found to be $0.10 \mathrm{~m}$ and $0.12 \mathrm{~m}$, respectively. The water flow rate in lined watercourse was computed with the help of Eq. (1) and found to be $0.0058 \mathrm{~m}^{3} / \mathrm{sec}(5.8 \mathrm{lps})$. As far as, the measurement of water flow rate in unlined watercourse is concerned, the Parshall flumes were installed at the upstream end and the downstream end of the channel. After sometime of installation when the flow gets stabilised, the heads at the converging section $\left(h_{a}\right)$ and the throat $\left(h_{b}\right)$ of the flume were recorded as $17 \mathrm{~cm}(0.56 \mathrm{ft})$ and $16 \mathrm{~cm}(0.52$ $\mathrm{ft}$ ) at the upstream end of channel while $16 \mathrm{~cm}$ (ft) and $15 \mathrm{~cm}$ (ft) at the downstream end, respectively.

The flow of water through the flume was observed to be under submerged condition and the degree of submergence was estimated using the Eq. (2). Using the chart developed by Robinson (1957), the water flow rate through the flume installed at upstream end and downstream end of the unlined watercourse and working under submerged condition were found to be $0.0068 \mathrm{~m}^{3} / \mathrm{sec}(6.8$ lps) and $0.0062 \mathrm{~m}^{3} / \mathrm{sec}(6.2 \mathrm{lps})$, respectively. The average rate of water flow was found to be higher in unlined watercourse $(6.5 \mathrm{lps})$ than that in lined watercourse $(5.8 \mathrm{lps})$.

\section{Measurement of water flow characteristics}

The characteristics of water flow in lined watercourse such as depth of flow and top width of flow were measured at upstream, middle and downstream sections of the watercourse and other characteristics of flow such as wetted perimeter, cross-sectional area, hydraulics radius and velocity of flow of water in the watercourse were determined and numerical value of these parameters were presented in Table 3. The average value of the depth of flow, top width of flow of water in lined water course were recorded as $0.047 \mathrm{~m}$ and $0.49 \mathrm{~m}$, respectively. However, the average value of the wetted perimeter, crosssectional area, hydraulics radius and the velocity of flow of water in the water course were found to be $0.59 \mathrm{~m}, 0.0225 \mathrm{~m}^{2}, 0.038 \mathrm{~m}$ and $0.269 \mathrm{~m} / \mathrm{s}$, respectively (Table 3 ). On the other hand, the depth and top width of flow of 
water in unlined watercourse were measured at seven sections of the watercourse and other characteristics of flow such as wetted perimeter, cross-sectional area, hydraulics radius and velocity of flow of water in the watercourse were computed and presented in Table 4. The average value of the depth of flow, top width of flow of water in unlined watercourse were found to be as $0.162 \mathrm{~m}$ and $0.993 \mathrm{~m}$, respectively.

Whereas, the average value of wetted perimeter, cross-sectional area, hydraulics radius and the velocity of flow of water in unlined watercourse were found to be 1.113 $\mathrm{m}, \quad 0.107 \mathrm{~m}^{2}, 0.096 \mathrm{~m}$ and $0.067 \mathrm{~m} / \mathrm{s}$, respectively (Table 4). It can be concluded that the velocity of flow were higher in lined watercourse $(0.269 \mathrm{~m} / \mathrm{s})$ than that in unlined watercourse $(0.069 \mathrm{~m} / \mathrm{s})$. The lower crosssectional area of flow $\left(0.0225 \mathrm{~m}^{2}\right)$ in lined watercourse was observed in comparison of that in unlined watercourse $\left(0.107 \mathrm{~m}^{2}\right)$. However, higher depth of flow in unlined watercourse $(0.162 \mathrm{~m})$ than that in lined watercourse $(0.047 \mathrm{~m})$ was observed.

\section{Computation of manning's roughness coefficient}

The Manning's roughness coefficient $(n)$ for the flow of water upstream, middle and downstream sections of lined watercourse was estimated with the help of Eq. (5) and presented in the Table 3. Table 3 shows the average value of Manning's roughness coefficient of 0.0551 . In the case of unlined watercourses, the selected length of watercourse were divided into six test sections and at the end of each test sections, the Manning's roughness coefficient was determined using Eq. (5) and presented in Table 4. Table 4 depicted that the minimum value of Manning's roughness coefficient of 0.103 and the maximum value of 0.183 . Whereas the average value of the
Manning's roughness coefficient for the unlined watercourse was observed to be 0.148 (Table 4).

The scatter plots between the Manning's roughness coefficient and the hydraulic radius of lined and unlined watercourses were plotted and shown in figure 1 and 2, respectively. The figures 1 and 2 depicted the increasing trend of Manning's roughness coefficient with increasing value of hydraulic radius of the lined and unlined watercourses, respectively. The highest values of correlation of $99.50 \%$ and $95.11 \%$ between Manning's roughness coefficient and hydraulics radius of the lined and unlined water courses respectively were obtained.

Attempt was made to establish the relationship between the Manning's roughness coefficient and the velocity of flow water in both the water courses. The scatter plots between the Manning's roughness coefficient and the velocity of flow water in both the watercourses were drawn and shown in figures 3 and 4, respectively. The decreasing trend between the Manning's roughness coefficient and the velocity of flow water in both the lined and unlined watercourses were observed. However, the highest values of correlation of $99.83 \%$ and $99.39 \%$ between Manning's roughness coefficient and velocity of flow in the lined and unlined water courses respectively were found.

\section{Computation of water loss during the flow}

The rate of water lost during the flow in unlined watercourse was determined. The loss of water flow rate in terms of seepage rate per unit length of the watercourse, percentage of loss of water flow rate and in terms of seepage rate per unit wetted area of the watercourse were computed by using the Eqns. (6), (7) and (8), respectively. The 
efficiency of unlined watercourse was estimated with the help of Eq. (9) and the values of these parameters were shown in Table 5. Table 5 showed the average wetted area of each test sections of $5.53 \mathrm{~m}^{2}$. The average conveyance loss of water flow rate per unit wetted area of unlined watercourse was estimated as $0.01811 \mathrm{ps} / \mathrm{m}^{2}$.

The amount of water lost during the 12 hour operation of unlined watercourse was estimated as 782 litres/day/ $/ \mathrm{m}^{2}$. The seepage rate of water flow per unit length of unlined watercourse was found to be $0.21 \mathrm{ps} / \mathrm{m}$ whereas the percentage loss of water flow rate between the upstream and downstream end of the unlined watercourse was observed to be $8.82 \%$. The conveyance efficiency of the unlined watercourse was estimated as $91.18 \%$. It was tried to correlate the depth of flow with the conveyance loss of water flow rate and the graph between them was shown in figure 5. The figure 5 showed the decreasing loss of water flow rate with the decreasing depth of flow in the unlined watercourse.

Table.1 Computation of bed slope of lined watercourse located at Chhounia field, Pusa

\begin{tabular}{|c|c|c|c|c|c|c|c|c|}
\hline \multirow{2}{*}{$\begin{array}{c}\text { No. } \\
\text { of } \\
\text { Obs. }\end{array}$} & \multicolumn{2}{|c|}{$\begin{array}{l}\text { Observations of } \\
\text { level staff }(\mathrm{m})\end{array}$} & \multirow[t]{2}{*}{$\begin{array}{l}\mathbf{H I} * \\
(\mathbf{m})\end{array}$} & \multicolumn{2}{|c|}{ Reduced level (m) } & \multirow{2}{*}{$\begin{array}{l}\text { Differenc } \\
\text { e in } \\
\text { elevation } \\
\text { (m) }\end{array}$} & \multirow{2}{*}{$\begin{array}{c}\text { Bed } \\
\text { slope } \\
(\%)\end{array}$} & \multirow{2}{*}{$\begin{array}{c}\text { Average } \\
\text { value of } \\
\text { slope } \\
(\%)\end{array}$} \\
\hline & U/s end & $D / s$ end & & U/s end & D/s end & & & \\
\hline 1 & 1.540 & 1.780 & \multirow{6}{*}{$\begin{array}{l}\stackrel{+}{n} \\
\stackrel{0}{0}\end{array}$} & 100.00 & 99.76 & 0.24 & 1.50 & \multirow[t]{6}{*}{1.50} \\
\hline 2 & 1.490 & 1.730 & & 100.05 & 99.81 & 0.24 & 1.50 & \\
\hline 3 & 1.550 & 1.790 & & 99.99 & 99.75 & 0.24 & 1.50 & \\
\hline 4 & 1.540 & 1.780 & & 100.00 & 99.76 & 0.24 & 1.50 & \\
\hline 5 & 1.525 & 1.765 & & 100.02 & 99.78 & 0.24 & 1.50 & \\
\hline 6 & 1.560 & 1.800 & & 99.98 & 99.74 & 0.24 & 1.50 & \\
\hline
\end{tabular}

* indicates the height of instrument (dumpy level).

Table.2 Computation of bed slope of unlined watercourse located at KendriyaVidyalaya, Pusa

\begin{tabular}{|c|c|c|c|c|c|c|}
\hline $\begin{array}{l}\text { No. of } \\
\text { Obs. }\end{array}$ & $\begin{array}{l}\text { Level staff } \\
\text { reading } \\
\text { (m) }\end{array}$ & $\begin{array}{l}\text { HI } * \\
(\mathbf{m})\end{array}$ & $\begin{array}{l}\text { Reduced } \\
\text { level }(\mathbf{m})\end{array}$ & $\begin{array}{l}\text { Difference in } \\
\text { elevation }(m)\end{array}$ & $\begin{array}{c}\text { Slope of } \\
\text { test } \\
\text { section }\end{array}$ & $\begin{array}{l}\text { Weighted } \\
\text { average of } \\
\text { bed slope }\end{array}$ \\
\hline 1 & 1.120 & \multirow[t]{6}{*}{101.120} & 100.000 & & & \\
\hline 2 & 1.125 & & 99.995 & 0.005 & 0.1 & \multirow[t]{5}{*}{0.2} \\
\hline 3 & 1.140 & & 99.980 & 0.015 & 0.3 & \\
\hline 4 & 1.140 & & 99.980 & 0.000 & 0.0 & \\
\hline 5 & 1.170 & & 99.950 & 0.030 & 0.6 & \\
\hline 6 & 1.180 & & 99.940 & 0.010 & 0.2 & \\
\hline
\end{tabular}

* indicates the height of instrument (dumpy level) 
Table.3 Determination of Manning's roughness coefficient and water flow characteristics in lined watercourse

\begin{tabular}{|c|c|c|c|c|c|c|c|}
\hline \multirow[t]{2}{*}{ Observations } & \multicolumn{5}{|c|}{ Characteristics of water flow in lined watercourse } & \multirow{2}{*}{$\begin{array}{c}\text { Velocit } \\
\text { y of } \\
\text { flow } \\
(\mathbf{m} / \mathbf{s})\end{array}$} & \multirow{2}{*}{$\begin{array}{l}\text { Manning's } \\
\text { Roughness } \\
\text { Coefficient } \\
\text { (n) }\end{array}$} \\
\hline & $\begin{array}{l}\text { Depth of } \\
\text { flow(m) }\end{array}$ & $\begin{array}{c}\text { Top } \\
\text { width } \\
(\mathrm{m})\end{array}$ & $\begin{array}{l}\text { Wetted } \\
\text { Perimeter } \\
(\mathrm{m})\end{array}$ & $\begin{array}{c}\text { Cross- } \\
\text { sectional } \\
\text { Area }\left(\mathrm{m}^{2}\right)\end{array}$ & $\begin{array}{c}\text { Hydraulic } \\
\text { Radius } \\
\text { (m) }\end{array}$ & & \\
\hline Upstream section & 0.03 & 0.56 & 0.62 & 0.0168 & 0.027 & 0.345 & 0.0318 \\
\hline Middle section & 0.05 & 0.46 & 0.56 & 0.0230 & 0.041 & 0.252 & 0.0577 \\
\hline $\begin{array}{l}\text { Downstream } \\
\text { section }\end{array}$ & 0.06 & 0.46 & 0.58 & 0.0276 & 0.047 & 0.210 & 0.0759 \\
\hline Average value & 0.047 & 0.49 & 0.59 & 0.0225 & 0.038 & 0.269 & 0.0551 \\
\hline
\end{tabular}

Table.4 Determination of Manning's roughness coefficient and water flow characteristics in unlined watercourse

\begin{tabular}{|c|c|c|c|c|c|c|c|}
\hline \multirow{2}{*}{$\begin{array}{l}\text { No. of } \\
\text { Obs. }\end{array}$} & \multicolumn{5}{|c|}{ Characteristics of water flow in lined watercourse } & \multirow{2}{*}{$\begin{array}{c}\text { Flow } \\
\text { velocity } \\
(\mathbf{m} / \mathbf{s})\end{array}$} & \multirow{2}{*}{$\begin{array}{l}\text { Manning's } \\
\text { roughness } \\
\text { coefficient } \\
\text { (n) }\end{array}$} \\
\hline & $\begin{array}{l}\text { Depth of } \\
\text { flow }(m)\end{array}$ & $\begin{array}{c}\text { Top } \\
\text { width(m) }\end{array}$ & $\begin{array}{c}\text { Wetted } \\
\text { perimeter }(m)\end{array}$ & $\begin{array}{c}\text { Cross- } \\
\text { sectional } \\
\text { Area }\left(\mathrm{m}^{2}\right)\end{array}$ & $\begin{array}{l}\text { Hydraulic } \\
\text { radius } \\
\text { (m) }\end{array}$ & & \\
\hline 1 & 0.180 & 1.05 & 1.21 & 0.126 & 0.104 & 0.056 & 0.176 \\
\hline 2 & 0.170 & 1.04 & 1.25 & 0.118 & 0.094 & 0.060 & 0.154 \\
\hline 3 & 0.155 & 0.99 & 1.07 & 0.102 & 0.095 & 0.069 & 0.135 \\
\hline 4 & 0.172 & 1.04 & 1.13 & 0.119 & 0.105 & 0.059 & 0.183 \\
\hline 5 & 0.140 & 0.90 & 0.98 & 0.084 & 0.086 & 0.084 & 0.103 \\
\hline 6 & 0.149 & 0.94 & 1.04 & 0.093 & 0.089 & 0.075 & 0.121 \\
\hline 7 & 0.168 & 0.99 & 1.11 & 0.110 & 0.099 & 0.063 & 0.162 \\
\hline Average & 0.162 & 0.993 & 1.113 & 0.107 & 0.096 & 0.067 & 0.148 \\
\hline
\end{tabular}

Table.5 Computation of rate of seepage loss and conveyance efficiency of unlined water course

\begin{tabular}{|c|c|c|c|c|c|c|}
\hline $\begin{array}{c}\text { S. } \\
\text { No. }\end{array}$ & $\begin{array}{c}\text { Test } \\
\text { section }\end{array}$ & $\begin{array}{c}\text { Wetted Area } \\
\text { of test } \\
\text { section } \\
\left(\mathbf{m}^{2}\right)\end{array}$ & $\begin{array}{c}\text { Seepage rate } \\
\text { per unit } \\
\text { wetted area } \\
\left(\mathbf{l p s} / \mathbf{m}^{\mathbf{2}}\right)\end{array}$ & $\begin{array}{c}\text { Seepage rate } \\
\text { per unit } \\
\text { length } \\
\text { (lps/m) }\end{array}$ & $\begin{array}{c}\text { Loss of } \\
\text { water } \\
(\mathbf{\%})\end{array}$ & $\begin{array}{c}\text { Conveyance } \\
\text { efficiency } \\
(\mathbf{\%})\end{array}$ \\
\hline $\mathbf{1}$ & $0-5$ & 6.15 & 0.098 & 0.02 & 8.82 & 91.18 \\
\hline $\mathbf{2}$ & $5-10$ & 5.80 & 0.103 & & & \\
\hline $\mathbf{3}$ & $10-15$ & 5.50 & 0.109 & & & \\
\hline $\mathbf{4}$ & $15-20$ & 5.28 & 0.114 & & & \\
\hline $\mathbf{5}$ & $20-25$ & 5.05 & 0.119 & & & \\
\hline $\mathbf{6}$ & $25-30$ & 5.38 & 0.112 & & & \\
\hline & Average & $\mathbf{5 . 5 3}$ & $\mathbf{0 . 0 1 8 1}$ & & \\
\hline
\end{tabular}




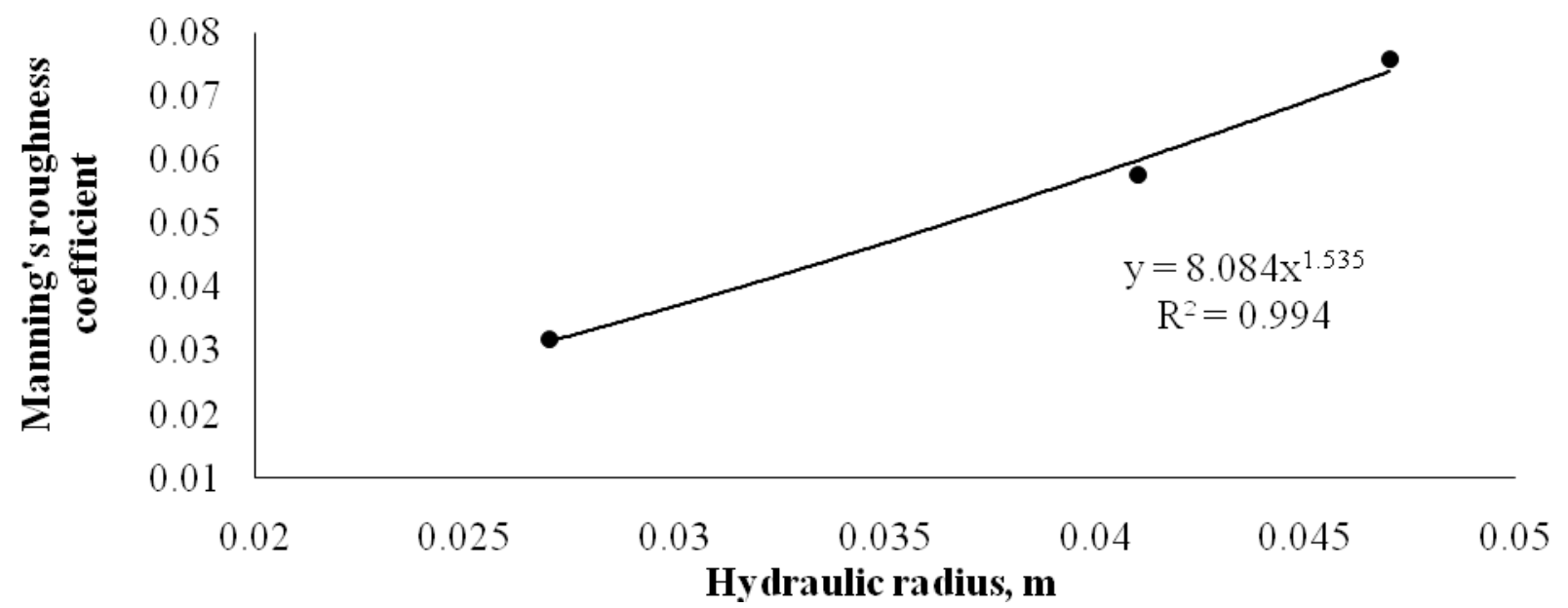

Fig.1 Scatter plot between Manning's roughness coefficient and hydraulic radius of flow in lined watercourse located at Chhounia field, Pusa

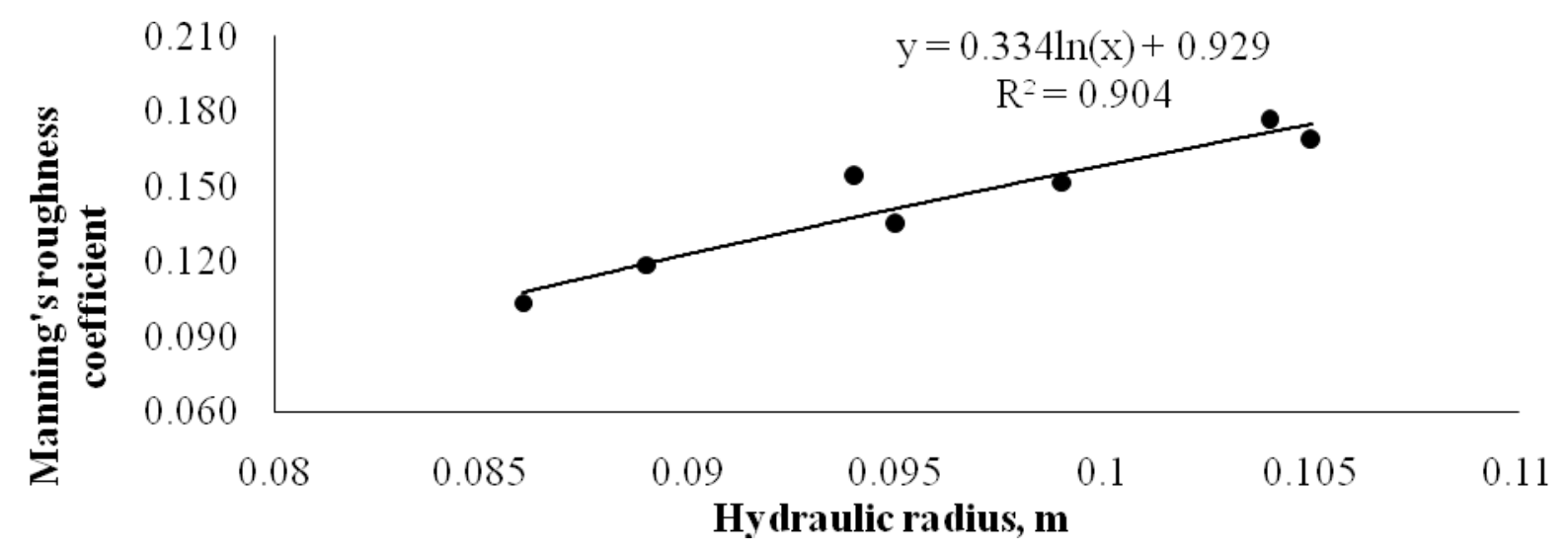

Fig.2 Scatter plot between Manning's roughness coefficient and hydraulic radius of flow in unlined watercourse located beside KV, Pusa

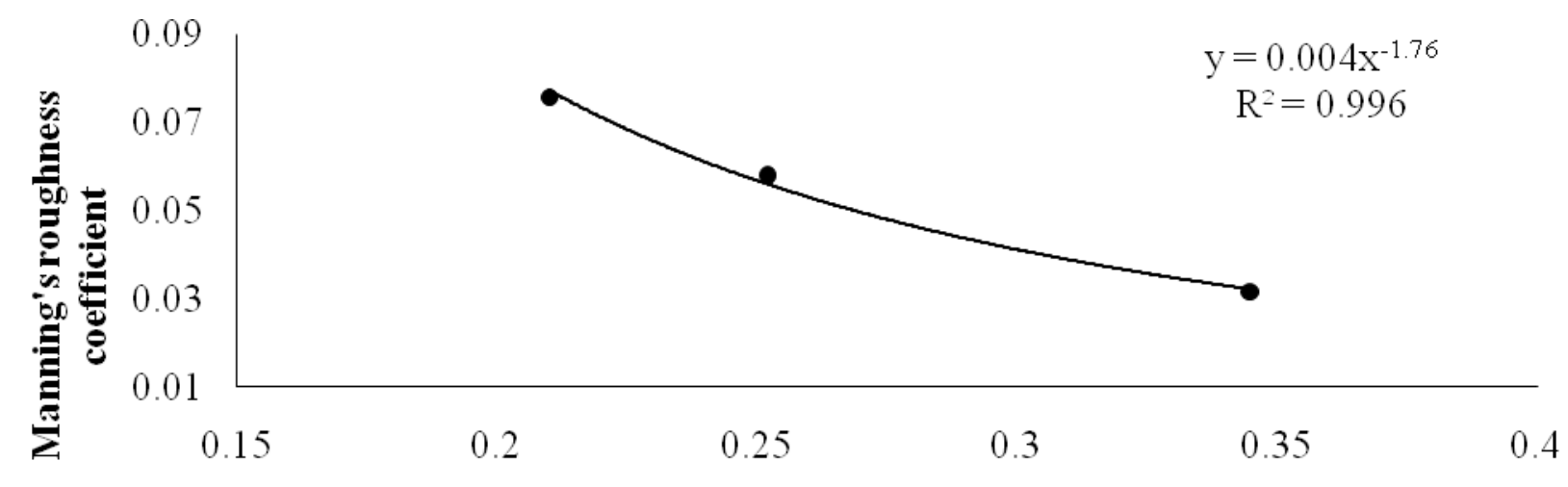

Flow velocity, $\mathbf{m} / \mathbf{s}$

Fig.3 Scatter plot between Manning's roughness coefficient and velocity of flow in lined watercourse located at Chhounia field, Pusa 


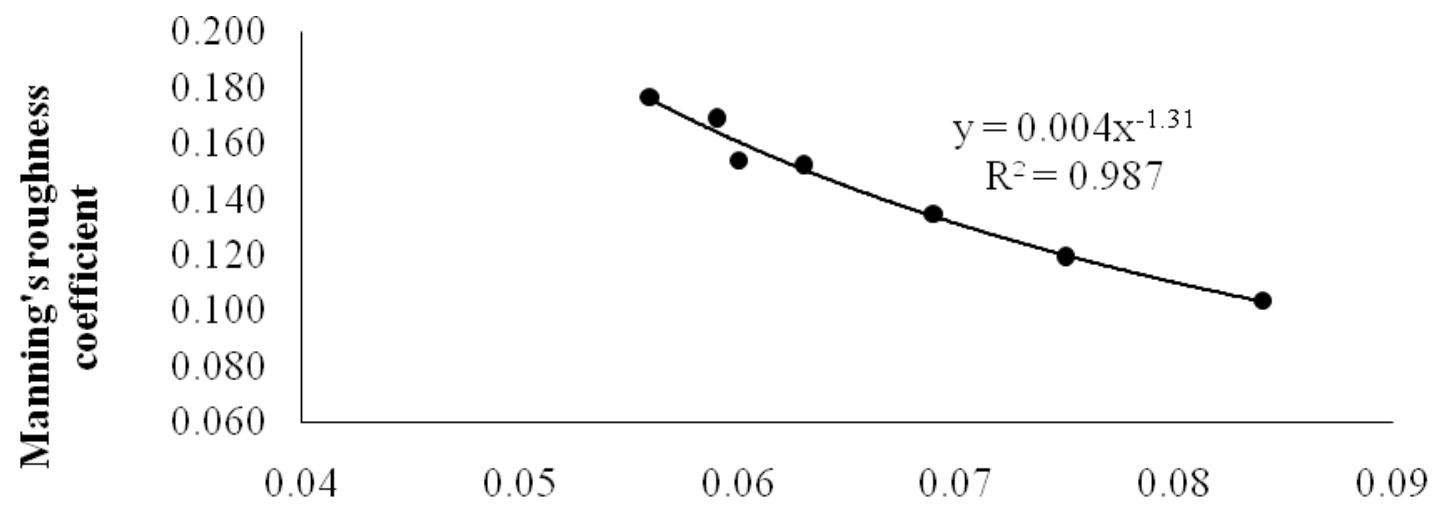

Flow velocity, $\mathbf{m} / \mathbf{s}$

Fig.4 Scatter plot between Manning's roughness coefficient and velocity of flow in unlined watercourse located beside KV, Pusa

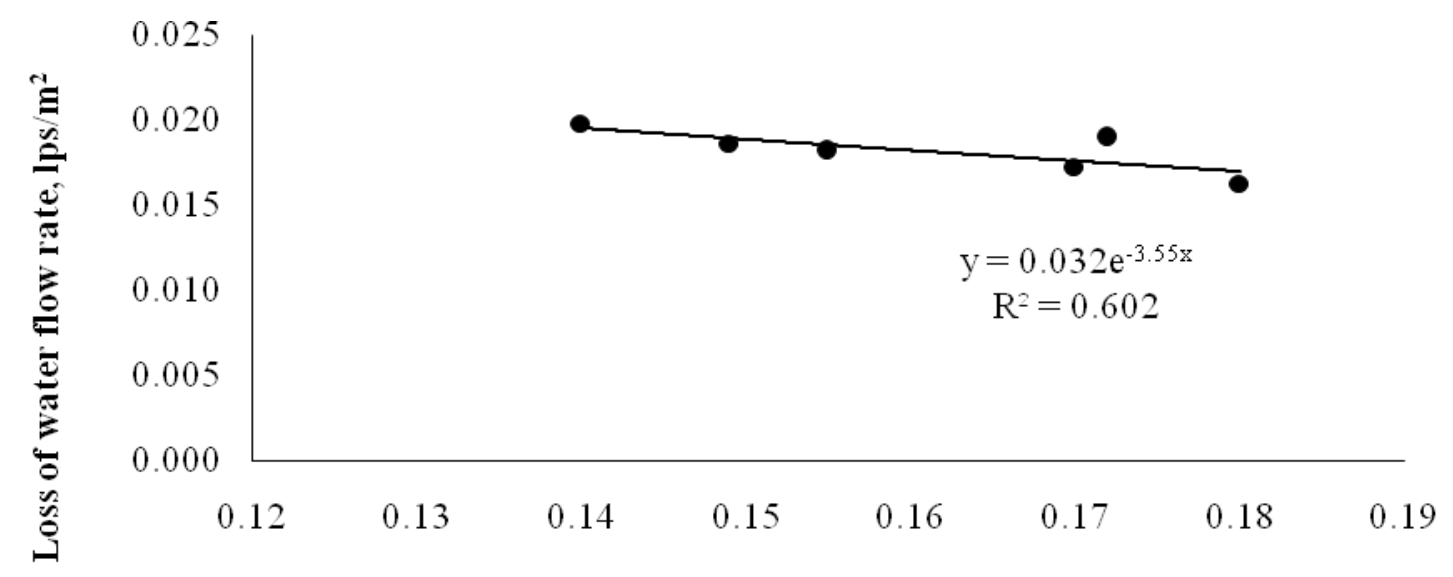

\section{Depth of flow, $m$}

Fig.5 Scatter plot between the conveyance loss of water flow rate and the depth of flow in unlined watercourse located beside KV, Pusa

1. The average bed slope of the lined watercourse was found to be $1.5 \%$ whereas that of unlined watercourse was observed to be $0.2 \%$.

2. The water flow rate in lined watercourse was observed to be $0.0058 \mathrm{~m}^{3} / \mathrm{sec}(5.8 \mathrm{lps})$ while that at upstream and downstream ends of the unlined watercourse were found to be $0.0068 \mathrm{~m}^{3} / \mathrm{sec}(6.8 \mathrm{lps})$ and $0.0062 \mathrm{~m}^{3} / \mathrm{sec}(6.2 \mathrm{lps})$, respectively.

3. The higher depth of flow of $0.162 \mathrm{~m}$ in unlined watercourse than that in lined watercourse $(0.047 \mathrm{~m})$ was observed.

4. The lower cross-sectional area of flow $\left(0.0225 \mathrm{~m}^{2}\right)$ in lined watercourse was observed in comparison of that in unlined watercourse $\left(0.107 \mathrm{~m}^{2}\right)$.

5. The velocity of flow was higher in lined watercourse $(0.269 \mathrm{~m} / \mathrm{s})$ than that in unlined watercourse $(0.069$ $\mathrm{m} / \mathrm{s})$.

6. The average value of Manning's roughness coefficient of 0.0551 was found in the lined watercourse whereas that in unlined watercourse 
was observed to be 0.148 .

7. The average conveyance loss of water flow rate per unit wetted area of unlined watercourse was revealed as $0.01811 \mathrm{ps} / \mathrm{m}^{2}$.

8. The seepage rate of water flow per unit length of unlined watercourse was found to be $0.2 \mathrm{lps} / \mathrm{m}$ whereas the percentage loss of water flow rate between the upstream and downstream end of the unlined watercourse was observed to be 8.82 $\%$.

9. The amount of water lost during the 12 hour operation of unlined watercourse was estimated as782 litres $/ \mathrm{day} / \mathrm{m}^{2}$.

10. The conveyance efficiency of the unlined watercourse was estimated as $91.18 \%$.

\section{Application of Research}

It is computed the Manning's roughness coefficient initiated during the flow in lined and unlined watercourses located at the Chhounia field near the field of AICRP on IWM and the Brick field beside the KV, Dr. RPCAU, Pusa (Bihar)

\section{Abbreviation and symbol}

$\begin{array}{ll}\mathrm{cm} & \text { Centimeter } \\ \mathrm{m} & \text { meter } \\ \% & \text { Percentage } \\ \mathrm{lps} & \text { Litter per Second } \\ \& & \text { And } \\ \mathrm{mm} & \text { millimeter } \\ { }^{\circ} & \text { Degree } \\ { }^{\circ} \mathrm{C} & \text { Degree Celsius } \\ \mathrm{n} & \text { Manning' s Coefficient } \\ \mathrm{Q} & \text { Discharge in watercourse } \\ \mathrm{L} & \text { Length of weir crest } \\ \mathrm{H} & \text { Head of the weir } \\ \mathrm{h}_{\mathrm{a}} & \text { Upstream } \\ \mathrm{h}_{\mathrm{b}} & \text { Downstream }\end{array}$

$\begin{array}{ll}\text { S } & \text { Slope } \\ \text { A } & \text { Area of unlined watercourse } \\ \text { t } & \text { Top width of the watercourse } \\ \text { d } & \text { Depth of flow } \\ \text { R } & \text { Hydraulic radius } \\ \text { V } & \text { Mean velocity } \\ \text { Q }_{L} & \text { Conveyance Loss }\end{array}$

\section{Acknowledgement/Funding}

Author thankful to Department of Irrigation and Drainage Engineering, College of Agricultural Engineering, Pusa, 848125, Dr.R.P.C.A.U. Pusa, Bihar, India.

\section{References}

Chang, T. H., Huang, S. T., Ches, S. and Lai, J. C. (2010). Estimation of manning's roughness coefficients on percast ecological concrete blocks. Journal of marine science and technology. 18 (2): 308-316.

Chow, V. T. (1559) Open channel hydraulic McGraw-Hill, New York

Datta, A. (1997). Dual roles for DNA sequence identity and the mismatch repair system in the regulation of mitotic crossing-over in yeast. Proc Natl Acad Sci U S 94 (18): 9757-62.

Khatua K. K., Patra K. C., Nayak P. ( 2012), "Meandering effect for evaluation of roughness coefficients in open channel flow" Sixth international conf. on river basin Management, WIT Transactions on Ecology and the Environment (ISSN 1743-3541), CMEM,WIT Press. 146(6):213-227.

Mitra, L., and Saikia, M. D. (2016). Analysis of flow resistance for different experimentally in open channels. International journal of innovation research is science, engineering and technology. 5 (2): 1817-1827.

Parhi, P. K., Sankhua, R. N., and Rry, G. P. 
2012. Calibration of channel roughness for Mahanadi River, (India) using HEC-RAS model. Journal of Water Resource and Protection. 4: $847-850$

Robinson, A. R. 1957. Parshall measuring flumes of small sizes. Fort Collins, Colorado 2 M: 1-57.

\section{How to cite this article:}

Pappu Kumar Paswan, Krishan Murari Sharma and Sudarshan Prasad. 2020. Estimate Roughness Coefficient and Water Lost During the Flow in the Watercourse Situated in the Pusa Farm. Int.J.Curr.Microbiol.App.Sci. 9(04): 908-920.

doi: https://doi.org/10.20546/ijcmas.2020.904.109
United Nations. (2013). The 2012 Revision, key findings and advance Tables. Department of Economic and Social Affairs, Population Division. World Population Prospects. Working Paper No. ESA/P/WP.227. 